\title{
Fluorescence of chlorophyll pigment in leaves of soft winter wheat annual at different stages of organogenesis
}

\author{
V. Starychenko, \\ L. Golyk, \\ Candidates of Agricultural Sciences \\ National Scientific Center "Institute of Agriculture of NAAS" \\ M. Patyka, \\ Doctor of Agricultural Sciences \\ National University of Bioresources and Natural Resources of Ukraine
}

The purpose. Study of physiological state of soft winter wheat at different stages of organogenesis by determination of amount and activity of chlorophyll pigment in probed plants and response of these cultivars to conditions of overwintering. Methods. The method is used of photoinduction of fluorescence of chlorophyll pigment which enables in field conditions to determine amount of chlorophyll pigment and photosynthetic rate of 7 cultivars of soft winter wheat. Results. The essential variance in amount and activity of chlorophyll pigment between cultivars at different stages of organogenesis is determined. The opportunity of estimation of winter-hardiness by means of method of induction of fluorescence of chlorophyll pigment is shown.

Key words: fluorescence of chlorophyll pigment, photosynthesis, high quality variance, winter-hardiness.

One of the modern and informative methods for determining the impact of environmental factors and physiological condition of agricultural crops is the use of a chlorophyll fluorescence analysis. Due to the fact that biochemical reactions causing photosynthesis and chlorophyll fluorescence are the main channels of conversion synthesized by absorbing light energy and transfer it to the photosynthetic reaction centers, rapid diagnosis of the physiological condition of plants makes it possible to obtain important information about the photosynthetic apparatus of plants [1].

The principle underlying the chlorophyll fluorescence analysis is relatively simple. Light energy absorbed by the molecules of chlorophyll in the leaves, can go one of three ways: to be used for photosynthesis (photochemistry), the excess energy can be dissipated as heat, or may re-emitted as fluorescence of chlorophyll. These three processes are in competition, any increase in efficiency will reduce one out of two others. Thus, by measuring chlorophyll fluorescence output can be obtained information about changes in the photochemistry efficiency and heat dissipation. Although the total amount of chlorophyll fluorescence is very small (only $1-2 \%$ of the absorbed light), measure it quite easily. Fluorescence spectrum different from the absorbed light with a peak fluorescence emission of longer wavelength than absorption. Thus, the yield of fluorescence can be quantified by lighting a leaf with light of a certain wavelength and measuring the amount of reflected light $[2,3,4]$.

In most research to measure parameters of photosynthesis plants use indicator of rapid fluorescence, scilicet of energy, which is not entered in the response of photosynthesis and is not passed in the heat after absorbing a photon cell [5]. The dependence of the fluorescence of time after the start of lighting called chlorophyll fluorescence induction curve (IFH) or induction curve [6, 7].

Photosynthesis - the process that provides the cell energy, so saving photosynthetic activity in terms of physiological stress in many cases determines the resistance of plants to adverse environmental factors. The focus of research was aimed at studying plant response to various stress factors $[8,9,10]$, while promising is study varietal differences for this indicator to be used in breeding. For soft wheat, this method was used to evaluate drought resistance and heat resistance of samples [12]. The aim of our research was 
to study the physiological condition of bread wheat at various stages of organogenesis by determining chlorophyll content in plants of six cultivars and varieties and its reaction for conditions of wintering.

\section{Conditions, materials and methods}

The study was conducted during the growing season in the field rotation DPDH "Chabany", KyivSviatoshynsky district, Kyiv region, Ukraine. The subject of the research served reflection spectra of chlorophyll fluorescence of soft wheat Myronivska 808 - St., Perlyna Lisostepy, Polisska 90, Analog, Stolychna, Artemida, Benefis. To measure used ten plants from three plots. Measurements were carried out in the phase of tillering (third decade of March) in the early phase of stem elongation (third decade of April) and in the flowering stage (end of May).

For study the state of the photosynthetic apparatus in plants using the method of induction of chlorophyll fluorescence (IHF) in the leaves, were carried out measuring the spectra of reflection and absorption of light leaves. Results are obtained in the form of Kautsky curve, which reflects the time dependence of fluorescence of chlorophyll. The shape of this curve is quite sensitive to changes that occur in the photosynthetic apparatus of plants in adapting to different environmental conditions [1, 2]. The essence of the method that the plant is kept in the dark and then illuminate for a while. Chlorophyll, which is located in the chloroplasts of leaves, shines (fluorescence). The strength of the glow first increases rapidly, reaches a maximum and then decreases at a fairly complicated trajectory until it reaches a certain fixed level. Schedule changes fluorescence light from the beginning to achieve a steady level (curve IHF) has information about the photosynthetic apparatus. From a practical purpose are using several standard quantitative indicators which are calculated based on this schedule [8].

Determination was carried out by fluorometer "Floratest" [11] for three minute mode. Physiologically significant data obtained by analyzing the kinetic parameters such as background or minimal fluorescence $\left(F_{0}\right)$, plateau $\left(F_{p}, F_{p l}\right)$, maximum fluorescence $\left(F_{m}\right)$ and steady-state fluorescence yield fluorescence $\left(F_{s}, F_{t}\right.$, $\left.F_{s t}\right)[1,2,10,11,12]$. To calculate, the consensus designation for steady-state fluorescence received $F_{s}$, because such a designation is most common in the literature published using Cyrillic. The literature on Latin consensus considered designation $\mathrm{F}_{\mathrm{t}}$ [2]. Parameters $F_{v}=F_{m}-F_{0}$ (variable fluorescence) [11] and the viability index $R F_{d}=F_{d} / F_{s}=\left(F_{m}-F_{s}\right) / F_{s}[8,13]$ calculated. The most useful is the parameter that measures the efficiency of Photosystem II photochemistry, $\Phi_{P S I I}$, calculated as: $\Phi_{P S I I}=\left(F_{m}-F_{t}\right) / F_{m}$. This parameter measures the proportion of light absorbed by chlorophyll associated with PSII (photosystem II) used in photochemistry. Thus, it can give as linear electron transport rate and the values of total photosynthesis [2]. According to the "Guidelines exploitation" used fluorometer [11], the parameter indicated as $K_{2}$ - coefficient of fluorescence induction. Under laboratory conditions, there is a strong linear relationship between this parameter and the efficiency of carbon fixation. Since $\Phi_{P S I}$ is the quantum yield of photosystem II photochemistry, it can be used to calculate the linear velocity of electron transfer and therefore the total photosynthetic capacity in vivo [2].

Another widely used option fluorescence measurement photochemistry is "photochemical quenching", $Q P$ [2]. This is calculated as: $Q P=\left(F_{m}-F_{t}\right) /\left(F_{m}-F_{0}\right)$, which gives an idea of the relationship between reaction centers of photosystem II, which are open. $\Phi_{P S / I}$ and $Q P$ can be connected via the third parameter, $F_{V} / F_{m}$. It is a measure of internal (or maximum) PSIl efficiency (quantum efficiency that is when all PSIl centers were opened). $F_{v} / F_{m}$ given by the equation: $F_{v} / F_{m}=\left(F_{m}-F_{0}\right) / F_{m}=\Phi_{P S I I} / Q P$. Thus, while $\Phi_{P S I I}$ refers to the achieved efficiency, $Q P$ and $F_{v} / F_{m}$ provide information about the processes underlying changes in the efficiency of photosynthesis. Changing $Q P$ is due to reaction centers closing as a result of saturation of photosynthesis light. Change $F_{v} / F_{m}$ efficiency due to a change non-photochemical quenching. The value of $F_{v} / F_{m}$ reflect the potential quantum efficiency PSII and used as a sensitive indicator of the performance of the photosynthetic apparatus of plants with optimum values of about 0.83 , measured for most plant species [2].

\section{Results and discussion}

Measurements of chlorophyll fluorescence in leaves of winter wheat at tillering stage (third decade of March) showed that highest major indicators were in varieties of winter wheat Benefis and Myronivska 808 (Table 1). Parameters maximum fluorescence $F_{m}$, viability index $R_{F d}$, total photosynthesis $\Phi_{P S I}$, 
photochemical quenching QP were highest in Benefis and amounted relative units, $0.93,0.48$ and 0.85 respectively, but the index of the potential efficiency of photosynthesis $F_{v} / F_{m}$ was highest in Myronivska 808.

Table 1. Parameters of chlorophyll fluorescence in leaves of bread wheat at tillering stage

\begin{tabular}{|l|r|r|r|r|r|r|r|r|r|}
\hline \multirow{2}{*}{\begin{tabular}{l} 
Varieties \\
\cline { 2 - 10 }
\end{tabular}} & \multicolumn{1}{|c|}{$F_{o}$} & \multicolumn{1}{|c|}{$F_{p}$} & \multicolumn{1}{|c|}{$F_{m}$} & \multicolumn{1}{c|}{$F_{s}$} & \multicolumn{1}{c|}{$F_{v}$} & $R F_{d}$ & $\Phi_{P S \|}$ & $Q P$ & $F_{v} / F_{m}$ \\
\hline $\begin{array}{l}\text { Myronivska } \\
\text { 808, St }\end{array}$ & 602,7 & 1290,7 & 1418,7 & 752,0 & 816,0 & 0,89 & 0,47 & 0,82 & 0,58 \\
\hline $\begin{array}{l}\text { Perlyna } \\
\text { Lisostepy }\end{array}$ & 570,7 & 1114,7 & 1162,7 & 672,0 & 592,0 & 0,73 & 0,42 & 0,83 & 0,51 \\
\hline Polisska 90 & 592,0 & 1104,0 & 1216,0 & 709,3 & 624,0 & 0,71 & 0,42 & 0,81 & 0,51 \\
\hline Analog & 656,0 & 1304,0 & 1320,0 & 776,0 & 664,0 & 0,70 & 0,41 & 0,82 & 0,50 \\
\hline Stolychna & 592,0 & 952,0 & 952,0 & 688,0 & 360,0 & 0,38 & 0,28 & 0,73 & 0,38 \\
\hline Artemida & 581,3 & 1162,7 & 1200,0 & 720,0 & 618,7 & 0,67 & 0,40 & 0,78 & 0,52 \\
\hline Benefis & 648,0 & 1408,0 & 1496,0 & 776,0 & 848,0 & 0,93 & 0,48 & 0,85 & 0,57 \\
\hline
\end{tabular}

Fluorescence curve of Stolychna (Fig. 1) shows that this variety at the time of measurement was depressed, what indicated by the low index of viability $R_{F d}=0,38$ too. Cultivars with the highest number and activity of chlorophyll on that date, Benefis and Myronivska 808, both with high winter hardiness, variety Myronivska 808 is a standard for winter hardiness.

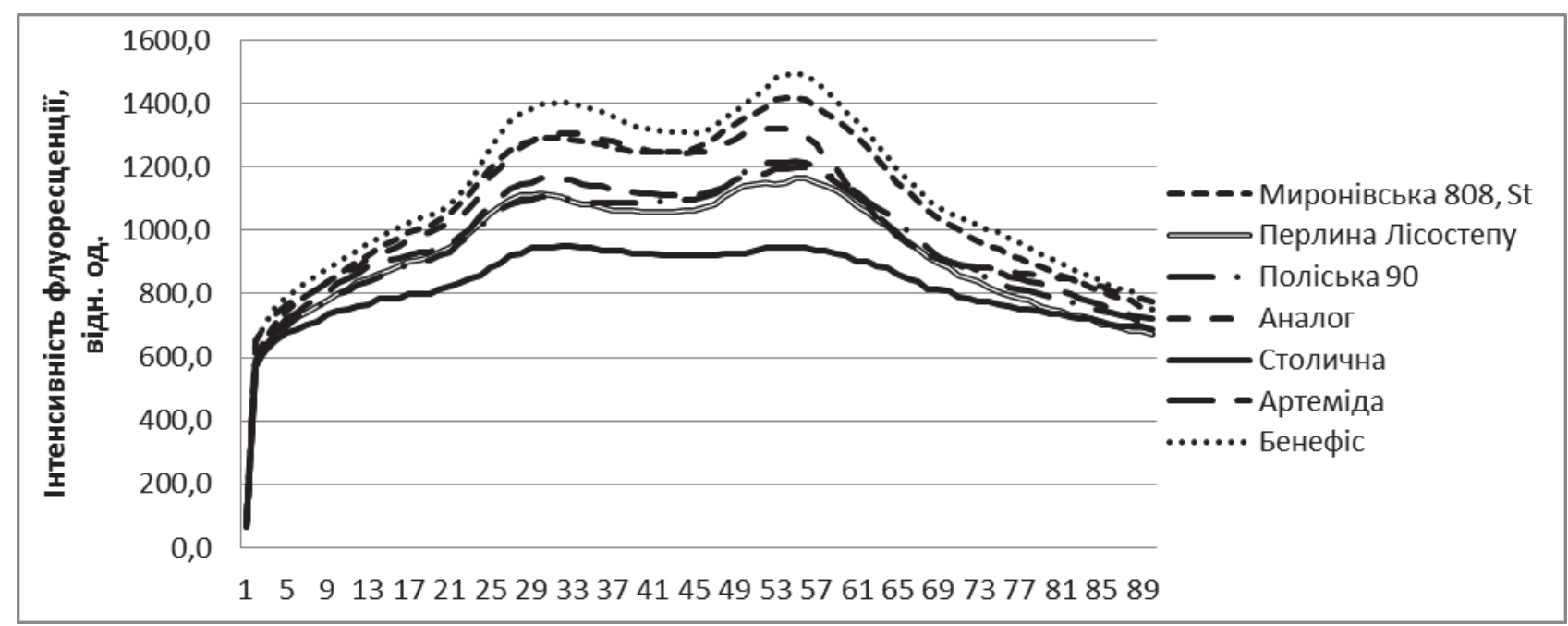

Fig. 1. The curve induced chlorophyll fluorescence in leaves of bread wheat, tillering phase

Induced chlorophyll fluorescence curves obtained in the phase of flowering (third decade of May) had a similar shape to the curves obtained earlier, with clear moments $F_{p}$ and $F_{m}$ (Fig. 2). It can be seen that the intensity of photosynthesis variety Myronivska 808 significantly decreased, $\mathrm{Fm}$ is less than 1000 units. It should be noted that this cultivar of relates to the previous generation and therefore has a lower yield compared to other represented varieties. Probably the low rate of photosynthesis during flowering is one of the reasons for lower productivity. 


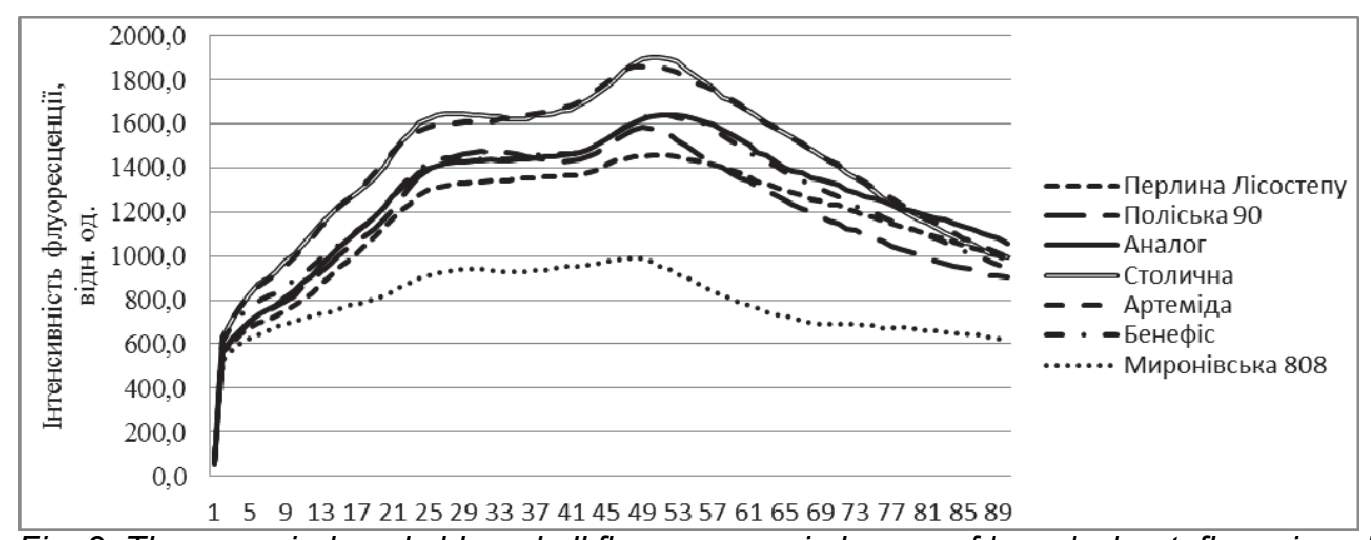

Fig. 2. The curve induced chlorophyll fluorescence in leaves of bread wheat, flowering phase

The highest chlorophyll content and photosynthetic intensity during this period marked the varieties Stolychna and Artemida, slightly worse - the varieties Benefis Polisska and 90, as evidenced by the high rate $F_{m}$, and high index of vitality and overall efficient photosynthesis (Table. 2). The lowest viability index during this period marked in the varieties Perlyna Lisostepy and Analog and the lowest performance index photosynthetic apparatus $F_{v} / F_{m}$ - in Myronivska 808.

Table 2. Parameters of chlorophyll fluorescence in leaves of bread wheat in flowering phase

\begin{tabular}{|c|c|c|c|c|c|c|c|c|c|}
\hline \multirow[b]{2}{*}{ Varieties } & \multicolumn{5}{|c|}{ Parameters, relative units } & \multicolumn{4}{|c|}{ Indices } \\
\hline & $F_{o}$ & $F_{p}$ & $F_{m}$ & $F_{s}$ & $F_{v}$ & $R F_{d}$ & $\Phi_{P S \|}$ & $Q P$ & $F_{v} / F_{m}$ \\
\hline $\begin{array}{l}\text { Myronivska 808, } \\
\text { St }\end{array}$ & 528,0 & 938,7 & 986,7 & 618,7 & 458,7 & 0,59 & 0,37 & 0,80 & 0,46 \\
\hline $\begin{array}{l}\text { Perlyna } \\
\text { Lisostepy }\end{array}$ & 560,0 & 1350,0 & 1454,0 & 976,0 & 894,0 & 0,49 & 0,33 & 0,53 & 0,61 \\
\hline Polisska 90 & 560,0 & 1477,0 & 1584,0 & 901,3 & 1024,0 & 0,76 & 0,43 & 0,67 & 0,65 \\
\hline Analog & 565,0 & 1472,0 & 1637,0 & 1056,0 & 1072,0 & 0,55 & 0,35 & 0,54 & 0,65 \\
\hline Stolychna & 632,0 & 1440,0 & 1909,0 & 992,0 & 1277,0 & 0,92 & 0,48 & 0,72 & 0,67 \\
\hline Artemida & 629,0 & 1648,0 & 1866,7 & 992,0 & 1237,7 & 0,88 & 0,47 & 0,71 & 0,66 \\
\hline Benefis & 613,0 & 1145,3 & 1637,3 & 944,0 & 1024,3 & 0,73 & 0,42 & 0,68 & 0,63 \\
\hline
\end{tabular}

Fig. 3 shows Kautsky curves for each of the varieties studied at three stages of organogenesis. Since the measurements were made simultaneously in all varieties, which belong to different groups of maturity, stages of some varieties may be somewhat biased. It is shown that the maximum amount of chlorophyll in leaves and photosynthesis intensity in most varieties observed in phase of stem elongation slightly lower - in the flowering stage and the minimum - in the phase of tillering. In the variety Stolychna marked the highest rate of photosynthesis in the flowering stage. The early maturing cultivar Analog had the highest rate of photosynthesis compared to other varieties in the measurement of the third decade of April, during phase of stem elongation, that we associate with its rapid development during this period. High-yielding varieties Stolychna and Artemida had increased the intensity of photosynthesis during flowering. Varieties Benefis and Myronivska 808 characterized most aligned curves Kautsky by stages of organogenesis. It is suggested that combination of high intensity of photosynthesis at all stages of organogenesis in one genotype by crossing appropriate parent pairs and further selection will provide samples from increased productivity of the photosynthetic apparatus. 

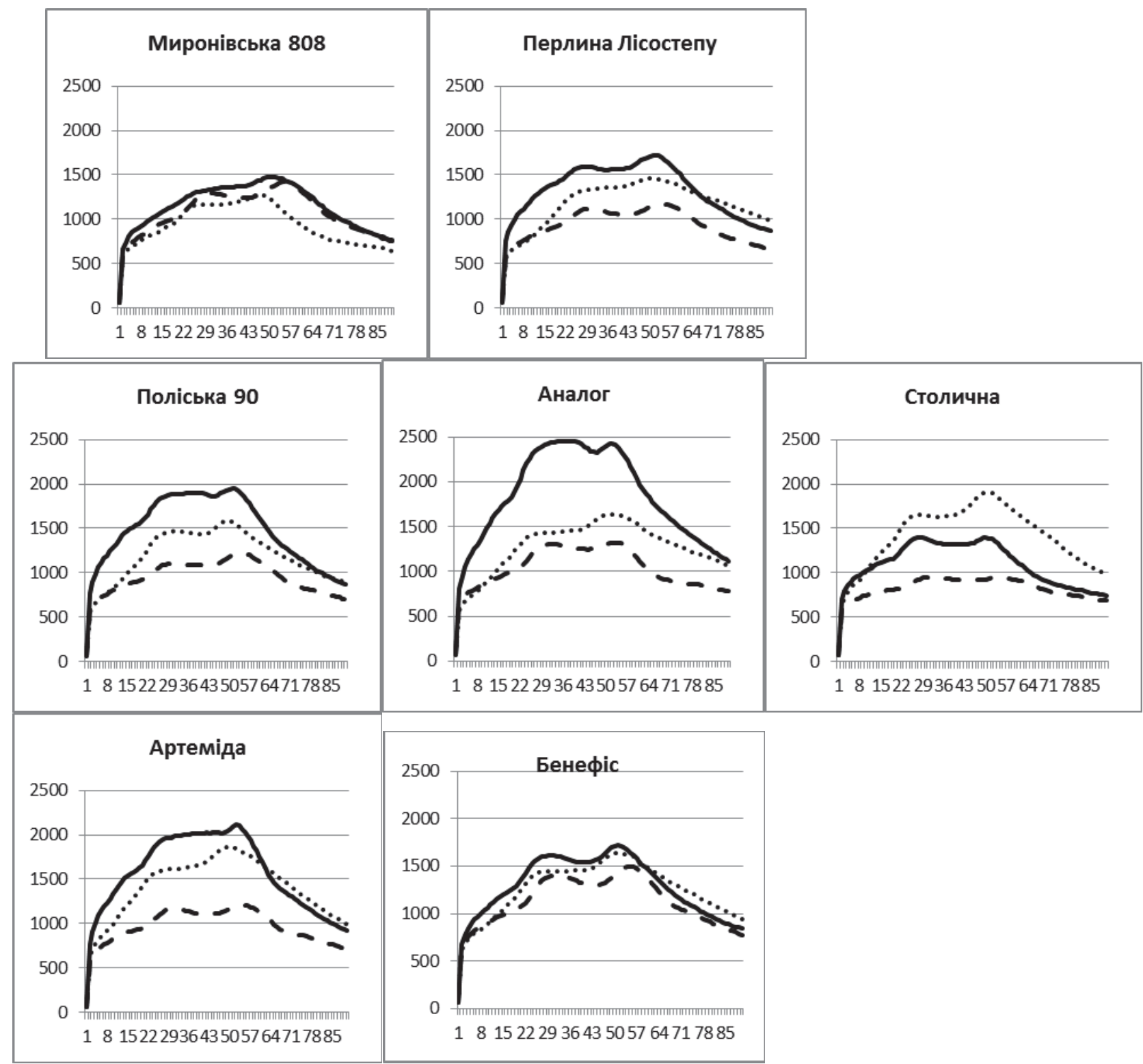

Fig. 3. Chlorophyll fluorescence in the phase:

-.---- tillering; —— stem elongation; ........ flowering.

Whereas known several parameters, which calculated based on the curve of chlorophyll fluorescence, were investigated correlations between these parameters to determine the usefulness of calculating each. The results are shown in Table 3, where the right side of the table shows the correlation coefficients between the parameters obtained in the tillering stage winter wheat, and on the left - in the flowering stage. In the tillering phase relationship between all the calculated index was sufficiently close, but in the phase of flowering only indices $\Phi_{P S I I}$ and $R_{F d}$ showed close relationship $(r=0,99)$. So, since these options overlap, the research can ignore one of them. 
Table 3. Correlations between parameters and indices chlorophyll fluorescence at different stages of organogenesis

\begin{tabular}{|c|c|c|c|c|c|c|c|c|c|}
\hline Parameters & $F_{o}$ & $F_{p}$ & $F_{m}$ & $F_{s}$ & $F_{v}$ & $R F_{d}$ & $\Phi_{P S I I}$ & $Q P$ & $\overline{F_{v} / F_{m}}$ \\
\hline$F_{o}$ & & 0,74 & 0,63 & 0,89 & 0,49 & 0,37 & 0,34 & 0,43 & 0,28 \\
\hline$F_{p}$ & 0,51 & & 0,76 & 0,89 & 0,93 & 0,87 & 0,85 & 0,79 & 0,83 \\
\hline$F_{m}$ & 0,88 & 0,81 & & 0,83 & 0,99 & 0,95 & 0,93 & 0,83 & 0,91 \\
\hline$F_{s}$ & 0,60 & 0,79 & 0,85 & & 0,74 & 0,60 & 0,58 & 0,49 & 0,49 \\
\hline$F_{v}$ & 0,84 & 0,84 & 1,00 & 0,87 & & 0,98 & 0,96 & 0,83 & 0,96 \\
\hline$R F_{d}$ & 0,80 & 0,42 & 0,68 & 0,20 & 0,65 & & 0,99 & 0,90 & 0,98 \\
\hline$\Phi_{P S I I}$ & 0,78 & 0,39 & 0,66 & 0,17 & 0,63 & 1,00 & & 0,91 & 0,84 \\
\hline$Q P$ & 0,11 & $-0,41$ & $-0,24$ & $-0,70$ & $-0,28$ & 0,54 & 0,56 & & 0,84 \\
\hline$F_{v} / F_{m}$ & 0,69 & 0,86 & 0,94 & 0,94 & 0,96 & 0,46 & $-0,50$ & $-0,50$ & \\
\hline
\end{tabular}

\section{Conclusions}

Thus, it was established differentiation of varieties for intensity of photosynthesis in various stages of organogenesis. Varieties with high intensity of photosynthesis in various stages were determined.

After wintering according to the results of induction of chlorophyll fluorescence in leaves best varieties of winter wheat were Benefis and Myronivska 808, known high winter hardiness. In the third week of April, at the beginning phase of stem elongation, the highest rate of photosynthesis noted in early maturing variety Analog. In the phase of flowering most intensive photosynthesis marked in varieties Stolychna and Perlyna Lisostepy, which have the highest potential productivity according to elements of the structure of the ear.

It is suggested the possibility of combining in one genotype high intensity of photosynthesis at all stages of organogenesis.

\section{Bibliography}

1. Patyka M.V., Grusha V.V., Gordijenko T. I. 2014. Monitoryng rostovyh procesiv roslyn v agrofitocenozah ekspres-metodom indukcii' fluorescencii' hlorofilu. Papers of NNC «Institute of agriculture of NAAS of Ukraine», Issue 3, 49-55.

2. Maxwell Kate, Giles N. Johnson. 2000. Chlorophyll fluorescence - a practical guide. Journal of experimental botany 51, Issue 345. 659-668.

3. Romanov V.A., Artemenko D.M., Brayko Ya.O., Galelyuka I.B., Imamutdinova R.G., Fedak V.S.2011. Portable devices of "Floratest" family: preparation for serial production. Proceedings of Institute "Computer means, networks and systems" 10. 85-93.

4. Korneev D. Ju. 2002. Ynformacyonny vozmozhnosty metoda yndukcyy fluorescencyy hlorofylla. K.: Al'terpres. 188.

5. Rubyn A.B. 2000. Byofyzycheskye metody $v$ эkologycheskom monytorynge Sorosovskyj obrazovatel'nyj zhurnal 6, №4. 7-13.

6. Brajon O. V, Kornjejev D. Ju., Snegur O. O., Kytajev O. I. 2000. Instrumental'ne vyvchennja fotosyntetychnogo apparatu za dopomogoju indukcii' fluorescencii' hlorofilu. Metodychni vkazivky dlja studentiv biologichnogo fakul'tetu K.: Vydavnycho-poligrafichnyj centr Kyi'vs'kogo universytetu. 15.

7. Medvedev S.S. 2004. Fyzyologyja rastenyj. Sankt-Peterburg: Yzdatel'stvo S.-Pet. Unyversyteta. 367.

8. Nesterenko T. V., Tyhomyrov A. A., Shyhov V. N. 2007. Chlorophyll fluorescence induction and estimation of plant resistance to stress factors. Zhurnal Obshchei Biologii (Journal of General Biology) 68 (6). 444-458.

9. Oleksijchenko N.O., Kytajev M.O. Sovakova O.V. Sovakov M.O. Borshhevs'kyj O.I. 2013. Osoblyvosti indukcii' fluorescencii' hlorofilu $v$ lystkah derevnyh roslyn $v$ umovah urbanizovanogo seredovyshha. Bioresursy i pryrodokorystuvannja 5, № 5-6. 107-112.

10. Sarahan Je.V. 2011. The features of applications of portable biosensor devices of "Floratest" family. Proceedings of Institute "Computer means, networks and systems" 10. 94-103.

11. Portatyvnyj fluorometr «Floratest» (nastanova z ekspluatacii'). 2011. Instytut kibernetyky im. V. M. Glushkova NAN Ukrai'ny. 27.

12. Sayed O.H. 2003. Chlorophyll fluorescence as a tool in cereal crop research. Photosynthetica 41 (3). 321-330.

13. Godlevs'ka O.O., Zaloi'lo I.A., Kozhem'jako Ja.V., Posudin Ju.I. 2011. Zastosuvannja portatyvnogo fluorymetra dlja ocinjuvannja rezystentnosti roslyn do biotychnyh faktoriv. Naukovyj visnyk NUBiP Ukrai'ny 161. 